\title{
Strategies: A Model of University Management
}

\author{
Juan Carlos Castro, Luis Chimborazo, Paola Guevara, Esmeralda Toapanta \\ Marketing Department, Technical University of Ambato, Ambato, Ecuador \\ Email: juanccastro@uta.edu.ec, le.chimborazo@uta.edu.ec, paola.guevara.uta@gmail.com, esmeralda.toapanta.uta@gmail.com
}

How to cite this paper: Castro, J.C., Chimborazo, L., Guevara, P. and Toapanta, E. (2017) Strategies: A Model of University Management. Journal of Service Science and Management, 10, 132-149. https://doi.org/10.4236/jssm.2017.102012

Received: January 18, 2017

Accepted: April 14, 2017

Published: April 17, 2017

Copyright (C) 2017 by authors and Scientific Research Publishing Inc. This work is licensed under the Creative Commons Attribution International License (CC BY 4.0).

http://creativecommons.org/licenses/by/4.0/

\begin{abstract}
The central purpose of the research was to design a strategic management model university for the self-assessment of the careers of the three area marketing, starting from an analysis of the eight best models applied in Europe and America, is contrasted the major components to determine the essential aspects of academic excellence which form part of the proposed model. The strategic axes of Management University proposed after the mentioned analysis there are six: Management University, teaching, student progress, support, research and University Social transcendence, distributed information in 12 areas, 28 features, 111 standards of quality, 188 indicators and 937evidences, validated by qualified informants issued by 28 opinions and documentary information.
\end{abstract}

\section{Keywords}

Strategic Planning, Accreditation, Evaluations by the University

\section{Introduction}

The universities in the 21st century take a new direction since the emergence of the universal phenomenon called globalization, this requires institutions of higher education (IES) to restructure their roles, objectives, goals and functions to the society, in effect, the dynamics of socio-economic growth, political, cultural, social and technological country requires the education sector generate potential solutions to reflect the quality of theoretical information received during the time of university education. For this reason, in today's society, is evident the creation of a quality higher education system.

Of the United Nations Organization for education, science and culture organization (UNESCO), and international organizations seek to institutionalize strategies that ensure quality expertise and professionals of excellence [1]. In this regard, higher education must assume the power to successfully respond to the new challenges it unfolds in the context of the generation of the 21st century, it 
is therefore essential to develop tools of management and organizational transformation of the IES growth which are in a process of innovation, achievement of academic excellence and University accreditation.

Higher education regulators demand standards of excellence, therefore the problem that is investigated is to design a strategic model of university management as a management tool for the accreditation of IES. Based on this research, is indisputable that the self-evaluation should contemplate guiding activities of university processes and act as an administrative instrument for institutional managers.

The IES should promote the development of peoples through education entering with greater social and ethical commitment in the generation of research centres and intellectual debate of quality, for the production of innovative solutions to local, regional or national problems. According to the new education system is essential to ensure maximum objectivity and impartiality in the college planning to obtain, with a view to meeting high standards to evaluate and believe, not only agencies that regulate the system of higher education, but also, in a society that relies on the quality that offer higher education.

According to the research, the objective is to design a model strategy of University management through the critical analysis of the theoretical construct and practical perspective a research historical-hermetical, defined in six strategic axes of the University. The hypothetical assumption is to verify whether the relevant management of the components of the model allows the accreditation of IES.

\section{Methodology}

The meta-analysis is a methodology that performs a remote and systematic review of the primary information collected for any type of study; the articles that are selected become evidence with high levels of quality, due to the conditions and criteria that must be met to form part of this process [2]. Furthermore, this methodology enables the logical organization of the literature and allows the comparison of the results of one research with another, this procedure guides the researcher to take objective decisions, to generate critical results and judgment about the effect analyzed [3] [4].

In fact, the technical richness and critical selection determines the quality of the theoretical construct of the strategic model of university management, guaranteeing a minimum bias of faults and validating each criterion applied in the model, consequently the integration of quantitative and qualitative results of the analyzed studies discard subjective propositions factors that disorient the fulfillment of the research objectives.

Figure 1 shows that the protocol aspects of the meta-analysis, the following were addressed: (a) description of the problem, which allowed the definition of the idea in precise, exact and explanatory terms; (b) a research question, to guide and delimit the study; (c) raise the initial statement of the behaviour of the investigated phenomenon and $(\mathrm{d})$ main purpose of the investigation. 


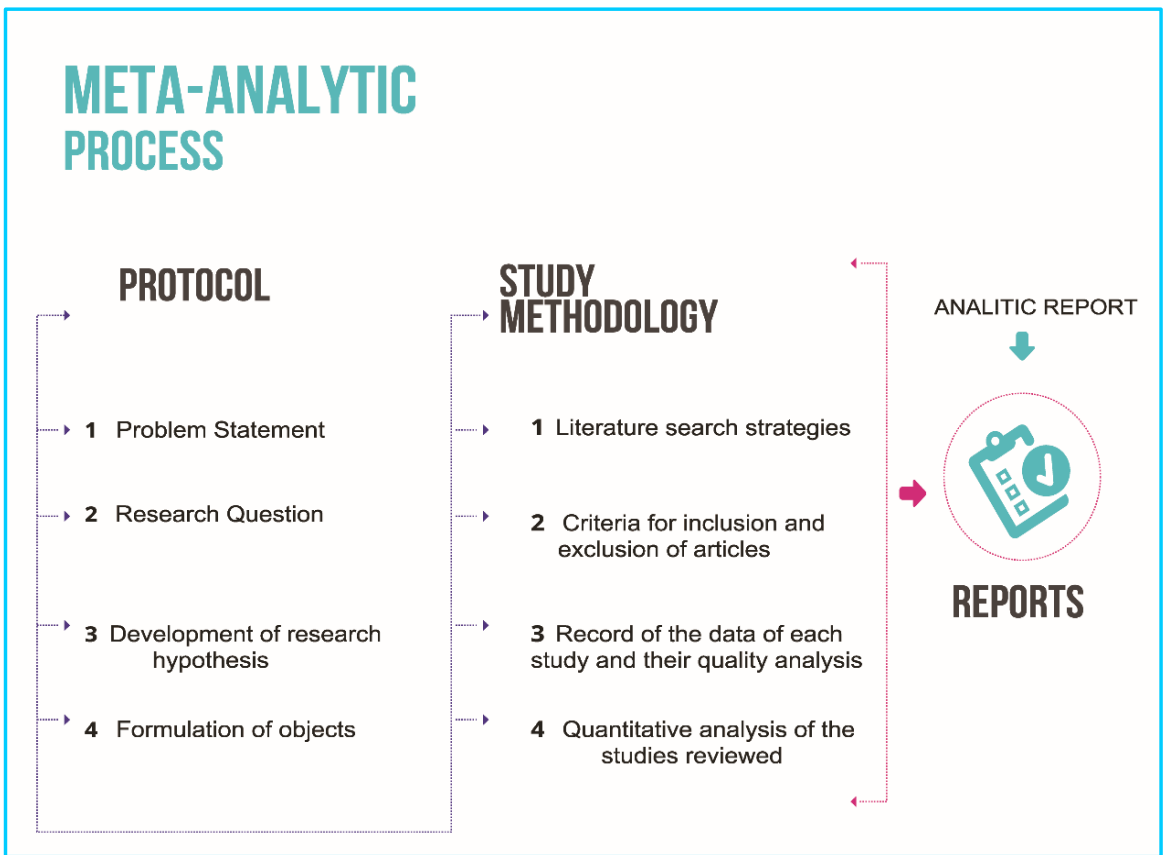

Figure 1. Meta-analytic process of study.

The methodology of the study is based on analysis of eight models of evaluation of the quality of higher education employees in America and Europe, through the institutions responsible for regulating criteria and indicators that enable to meet college academic excellence. To validate the Builder model theorist was performed quantitative analysis of 485 sources for (a) administrative management, were employed 112; (b) teaching, 54; (c) student progress, 34; (d) support services, 134; (e) research, 46 and (f) university social importance, 105 sources.

Literature search strategies were integrated combining different selection criteria, in order to make a segmentation of appropriate research studies [5]. The specialized search was based on: studies published as books, scientific and encyclopedia articles, and not published as documents, theses, institutional web pages, newspaper articles, interviews and conference articles. The magnitude of information demanded to delimit the search through key terms: strategic planning, accreditation and university evaluation. In addition, another significant element was to consider the time and cost that was used. As well as to keep a systematic register of the information cataloged through computer search managers [6].

Then it is essential to establish inclusion and exclusion criteria, which determine the optimal characteristics in common considering certain studies [7]. Subsequently, the quality of information was determined by the statistical calculation of the effect size of the test of homogeneity and heterogeneity, which is represented in a graph of forest plot that visually shows the similarities or differences between the analysed constructs of various studies was determined [8] [9]. Finally, the quantitative analysis of the sources reviewed according to the type of resource for each function was carried out. 
Table 1. Aspects of the protocol.

\begin{tabular}{cl}
\hline \multicolumn{1}{c}{ Aspects of the Protocol } \\
$\begin{array}{cl}\text { Problem } \\
\text { Statement }\end{array}$ & $\begin{array}{l}\text { ¿In what way the strategic model of university management influences the } \\
\text { accreditation of the marketing careers of zone three? }\end{array}$ \\
$\begin{array}{c}\text { Research } \\
\text { Question }\end{array}$ & $\begin{array}{l}\text { ¿What are the integral elements for the design of a strategic model of university } \\
\text { management for the marketing careers of zone three? }\end{array}$ \\
$\begin{array}{cl}\text { Research } \\
\text { Hypothesis }\end{array}$ & $\begin{array}{l}\text { The strategic model of university management, allows the accreditation of the } \\
\text { marketing careers of zone three. }\end{array}$ \\
$\begin{array}{c}\text { General } \\
\text { Objective }\end{array}$ & $\begin{array}{l}\text { To design a strategic model of university management for the accreditation of } \\
\text { the marketing careers of Zone three. }\end{array}$ \\
& $\begin{array}{l}\text { To analyse the different models of evaluation of the university quality for the } \\
\text { accreditation in the institutions of superior education. }\end{array}$ \\
Specific & $\begin{array}{l}\text { To base the construct of the criteria of study of the strategic model of university } \\
\text { management. }\end{array}$ \\
& $\begin{array}{l}\text { Identify the guidelines for the effective functioning of the strategic axes of } \\
\text { university development. }\end{array}$
\end{tabular}

\section{Results}

\subsection{Aspects of the Protocol}

Table 1 shows the guide for the development of the study based on the formalization of a strategic model that will improve university management for university management for accreditation purposes, landing in hypothetical starting scenarios as tentative axes for the definition of theoretical and operative constructs justified from the purpose of study purposes.

\subsection{Parted Models}

On the model of self-assessment for institutions of higher education, perfected by the Interuniversity Development Center (CINDA) of Chile, consists of five areas of specialization: teaching, research, extension, general academic area and management [10]; in a study of Casal, published in University and in Barcelona knowledge society determine the comparison of indicators of quality of models of evaluation of the 11 countries with the largest number of IES, included in the academic world ranking of universities, where grouped in seven categories: (a) educational program; (b) organization of education; (c) human resources; (d) material resources; (e) educational process; (f) results and $(\mathrm{g}$ ) research [11].

Moreover, the basic system of indicators for the higher education of Latin America, developed by the integrated information system on the institutions of education (INFOCES) in Valencia-Spain is made up of dimensions, sub- dimensions, categories and indicators: (a) structure, comprises three sub-dimensions landed on 12 indicators, (b) results consists of three sub-dimensions, eight categories and 25 indicators (c) context consists of a sub-dimension and seven indicators, generating a total of 44 indicators [12]; The Standards and Guidelines for Quality Assurance in the European Higher Education Area (ESG), prepared by the European Association for Quality Assurance in Higher Education, European 
Students Union, European University Association, the European Association of Institutions in Higher Education, Education International, BUSINESSEUROPE, European Quality Assurance Register for Higher Education, is composed of criteria and guidelines: (a) internal quality assurance in higher education institutions, (b) external quality assurance of higher education and (c) external quality assurance agencies [13].

In regards to the model of the development of indicators on education in Latin America and the Caribbean established by the United Nations Organization for education, science and culture (UNESCO), is comprised of five categories: (a) demographic, social and economic context and overview of the education system; (b) resources in education; (c) performance of educational systems; (d) quality in education and (e) social impact of education [14].

The model of academic performance indicators developed by the Latin American Association of colleges and schools of accounting and Administration (ALAFEC), presented at the 14th general Assembly of the institution in Panama consists of components, dimensions, categories, subcategories and indicators: (a) indicators by educational program and (b) concerning the academic entity [15]; The model institutional self-evaluation for accreditation by the Council for evaluation, accreditation and assurance of the quality of higher education (CONEA), is composed of four main functions: (a) administrative management, (b) teaching, (c) research and (d) bonding [16].

Finally, the generic model of evaluation of the environment of learning face-to-face careers and semi face-to-face of universities and polytechnic schools of Ecuador was analyze and also implemented by the CEAACES, consists of the criteria, and sub-criteria as well as indicators: (a) relevance, (b) curriculum, (c) Academy, (d) institutional environment and (e) students [17].

\subsection{Exclusion and Inclusion Criteria}

Qualify in three inclusion criteria: reliable databases, bibliographic information according to their age and language and four exclusion criteria: no reliable sources, older than five years, incomplete bibliographical information and paid databases.

\subsubsection{Reliable Data Bases}

About of Table 2, we could know the data bases used for the investigation with their according percentages and frequencies.

Analyzed 485 sources employed in the study of the strategic model of University management, is determined that $47 \%$ of the sources were found in the Google books database.

\subsubsection{Antiquity Information Related to Bibliography}

Bibliography resources according to year and publications, for each function of the following model are showed in Table 3.

Whereas the meta-analytic process, most of the sources employed in the six functions come from not older than five years: (a) administrative management, 
Table 2. Sources for strategic models, according to university data bases.

\begin{tabular}{|c|c|c|c|c|}
\hline & & Frequency & Percent & Valid percent \\
\hline & Scielo & 25 & 5.2 & 5.2 \\
\hline & Dialnet & 3 & 0.6 & 0.6 \\
\hline & Google Books & 228 & 47.0 & 47.0 \\
\hline & Institutional database & 115 & 23.7 & 23.7 \\
\hline & Redalyc & 7 & 1.4 & 1.4 \\
\hline & Others & 93 & 19.2 & 19.2 \\
\hline & E-lis & 2 & 0.4 & 0.4 \\
\hline & Amazon s3 & 1 & 0.2 & 0.2 \\
\hline & Sciencedirect & 1 & 0.2 & 0.2 \\
\hline \multirow[t]{10}{*}{ Valids } & Comercio & 2 & 0.4 & 0.4 \\
\hline & Dsia & 1 & 0.2 & 0.2 \\
\hline & Virtual health library publishes universe & 1 & 0.2 & 0.2 \\
\hline & Universo & 1 & 0.2 & 0.2 \\
\hline & Redulac & 1 & 0.2 & 0.2 \\
\hline & Signa & 1 & 0.2 & 0.2 \\
\hline & Cepal & 1 & 0.2 & 0.2 \\
\hline & Redicces & 1 & 0.2 & 0.2 \\
\hline & Researchgate & 1 & 0.2 & 0.2 \\
\hline & Total & 485 & 100.0 & 100.0 \\
\hline
\end{tabular}

Table 3. Types of resources based on antiquity.

\begin{tabular}{|c|c|c|c|c|}
\hline \multicolumn{5}{|c|}{ Antiquity } \\
\hline \multicolumn{5}{|c|}{ Administrative management } \\
\hline \multirow{6}{*}{ Valids } & & Frequency & Percent & Valid percent \\
\hline & $0-5$ & 108 & 96.4 & 96.4 \\
\hline & $6-10$ & 1 & 0.9 & 0.9 \\
\hline & Greater than 11 & 2 & 1.8 & 1.8 \\
\hline & Undated & 1 & 0.9 & 0.9 \\
\hline & Total & 112 & 100.0 & 100.0 \\
\hline \multicolumn{5}{|c|}{ Teaching } \\
\hline \multirow{4}{*}{ Valids } & $0-5$ & 52 & 96.3 & 96.3 \\
\hline & Greater than 11 & 1 & 1.9 & 1.9 \\
\hline & Undated & 1 & 1.9 & 1.9 \\
\hline & Total & 54 & 100.0 & 100.0 \\
\hline \multicolumn{5}{|c|}{ Student progress } \\
\hline Valids & $0-5$ & 34 & 100.0 & 100.0 \\
\hline \multicolumn{5}{|c|}{ Support services } \\
\hline \multirow{3}{*}{ Valids } & $0-5$ & 133 & 99.3 & 99.3 \\
\hline & Undated & 1 & 0.7 & 0.7 \\
\hline & Total & 134 & 100.0 & 100.0 \\
\hline
\end{tabular}


Continued

\begin{tabular}{lcccc}
\hline \multicolumn{5}{c}{ Research } \\
\hline Valids & $0-5$ & 46 & 100.0 & 100.0 \\
\hline \multirow{4}{*}{ Valids } & University social importance \\
& $0-5$ & 100 & 95.2 & 95.2 \\
& $6-10$ & 2 & 1.9 & 1.9 \\
& Greater than 11 & 1 & 1.0 & 1.0 \\
& Undated & 2 & 1.9 & 1.9 \\
& Total & 105 & 100.0 & 100.0
\end{tabular}

Table 4. Types of idiomatic resources.

\begin{tabular}{ccccc}
\hline & & Frequency & Percent & Valid percent \\
\hline \multirow{4}{*}{ Valids } & English & 19 & 3.9 & 3.9 \\
& Spanish & 465 & 95.9 & 95.9 \\
& Catalan & 1 & 0.2 & 0.2 \\
& Total & 485 & 100.0 & 100.0 \\
\hline
\end{tabular}

96.4\%; (b) teaching, 96.30\%; (c) student progress, 100\%; (d) support services, 99.3\%; (e) research, 100\% and (f) university social importance, $95.2 \%$.

\subsubsection{Language (Idiomatic)}

Table 4 indicates the bibliography resourcing based on language (Idiom) of the research paper.

After analyzing the 485 sources, determines that $95.83 \%$ are in Spanish language.

\subsection{Quality of Registered Data}

\subsubsection{Analysis of Homogeneity and Heterogeneity}

The analysis of homogeneity and heterogeneity of each function proposed for the model is pointed in Table 5.

Through this analysis determines the quality of information managed in the construct of the strategic model of university management, processing the sources is determined in each function homogeneity outperforms the heterogeneity with the following values: (a) administrative management, 62.50\%; (b)teaching, 61.10\%; (c) student progress, $61.80 \%$; (d) support services, $67.20 \%$; (e) research, $71.70 \%$ and (f) university social importance, $73.30 \%$.

\subsubsection{Size of the Homogeneity Test}

To determine the quality of information is processed data and it was considered criteria of homogeneity and heterogeneity, which was evaluated in the six functions of the model, the size of the effect of each study is represented by a square whose area is proportional to the weight "Weight" (WGHT (kg)), located in the fourth column of the right side of the graph, in the same way each study confidence interval is represented by lines parallel to the axis of the " $\mathrm{x}$ " located on 
Table 5. Analysis of homogeneity and heterogeneity.

\begin{tabular}{|c|c|c|c|c|}
\hline \multicolumn{5}{|c|}{ Homogeneity and Heterogeneity } \\
\hline \multicolumn{5}{|c|}{ Administrative management } \\
\hline & Homogeneity & 70 & 62.5 & 62.5 \\
\hline \multirow[t]{2}{*}{ Valids } & Heterogeneity & 42 & 37.5 & 37.5 \\
\hline & Total & 112 & 100.0 & 100.0 \\
\hline \multicolumn{5}{|c|}{ Teaching } \\
\hline \multirow{3}{*}{ Valids } & Homogeneity & 33 & 61.1 & 61.1 \\
\hline & Heterogeneity & 21 & 38.9 & 38.9 \\
\hline & Total & 54 & 100.0 & 100.0 \\
\hline \multicolumn{5}{|c|}{ Student progress } \\
\hline \multirow{3}{*}{ Valids } & Homogeneity & 21 & 61.8 & 61.8 \\
\hline & Heterogeneity & 13 & 38.2 & 38.2 \\
\hline & Total & 34 & 100.0 & 100.0 \\
\hline \multicolumn{5}{|c|}{ Support services } \\
\hline \multirow{3}{*}{ Valids } & Homogeneity & 90 & 67.2 & 67.2 \\
\hline & Heterogeneity & 44 & 32.8 & 32.8 \\
\hline & Total & 134 & 100.0 & 100.0 \\
\hline \multicolumn{5}{|c|}{ Research } \\
\hline \multirow{3}{*}{ Valids } & Homogeneity & 33 & 71.7 & 71.7 \\
\hline & Heterogeneity & 13 & 28.3 & 28.3 \\
\hline & Total & 46 & 100.0 & 100.0 \\
\hline \multicolumn{5}{|c|}{ University social importance } \\
\hline \multirow{3}{*}{ Valids } & Homogeneity & 77 & 73.3 & 73.3 \\
\hline & Heterogeneity & 28 & 26.7 & 26.7 \\
\hline & Total & 105 & 100.0 & 100.0 \\
\hline
\end{tabular}

each side of the size of the effect of study accordingly, $(0.1-1)$ homogeneity and heterogeneity $(1-2)$, values that are observed in the second column of lower level of confidence "Lower Confidence" (LCL) and in the third column the higher level of confidence "Upper Confidence" (UCL), in the middle of chart displays a vertical line that symbolizes the null studies effect i.e. they do not represent a significant value to determine the quality of information, value in the first column as "Odds Ratio" (OR), showing the difference half typified or relative risk with a value of one, the usefulness of this statistical index allows you to connect and compare all the results obtained through different qualitative assessment scales used in the studies reviewed. The overall effect was calculated using the average value of the impact of homogeneity and heterogeneity of the studies in each function, its value is 0.54 , figured in a rhombus; whose location shows us that there was greater homogeneity in the investigation, because it is located on the left side of the zero effect line, as shown in Figure 2. 


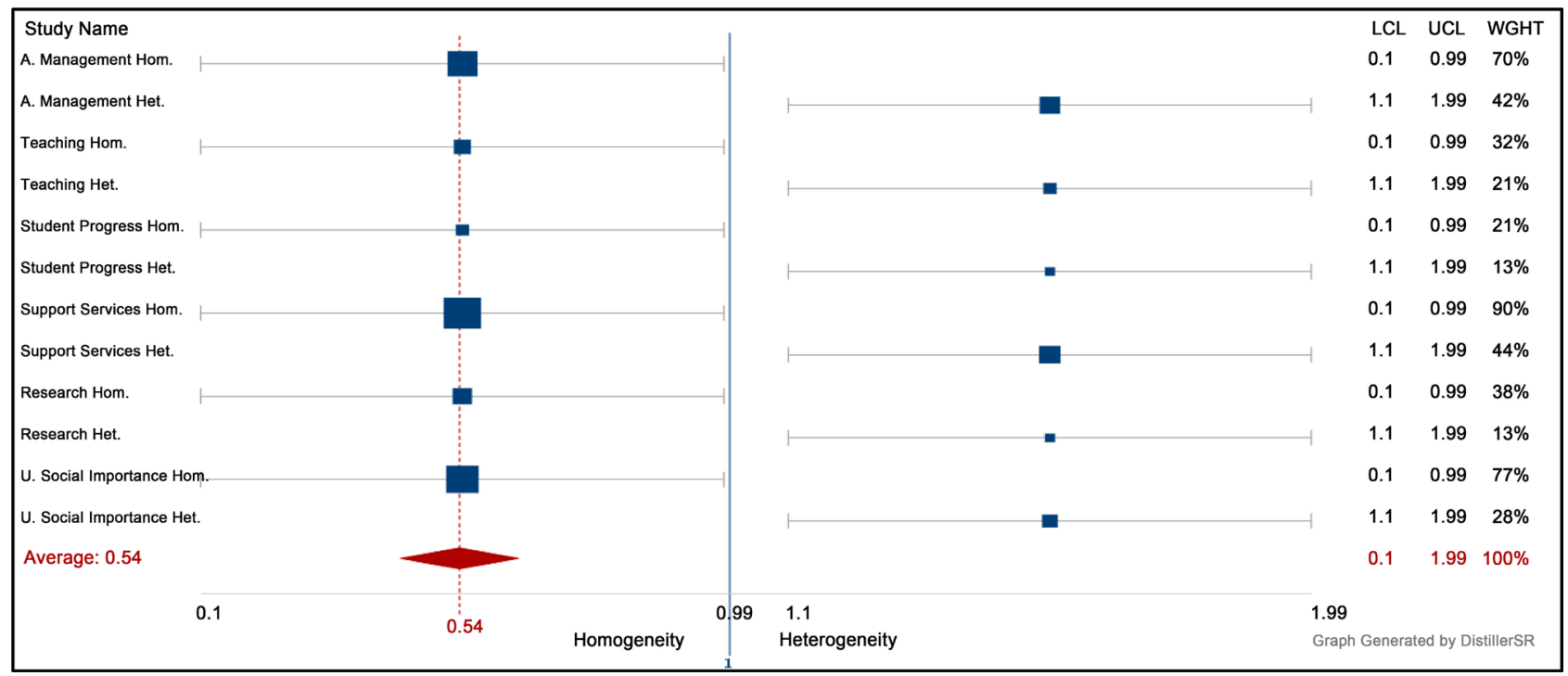

Figure 2. Plot or chart the size of the effect of the test of homogeneity and heterogeneity.

Table 6. Quantitive analysis of each function.

\begin{tabular}{|c|c|c|c|c|c|c|c|c|c|c|c|c|}
\hline \multirow{3}{*}{ Item Type } & \multicolumn{12}{|c|}{ Functions } \\
\hline & \multicolumn{2}{|c|}{$\begin{array}{l}\text { Administrative } \\
\text { management }\end{array}$} & \multicolumn{2}{|c|}{ Teaching } & \multicolumn{2}{|c|}{ Student progress } & \multicolumn{2}{|c|}{ Support services } & \multicolumn{2}{|c|}{ Research } & \multicolumn{2}{|c|}{$\begin{array}{l}\text { University social } \\
\text { importance }\end{array}$} \\
\hline & frequency & $\%$ & frequency & $\%$ & Frequency & $\%$ & frequency & $\%$ & frequency & $\%$ & frequency & $\%$ \\
\hline Books & 76 & $68 \%$ & 6 & $11 \%$ & 5 & $15 \%$ & 59 & $44 \%$ & 40 & $87 \%$ & 47 & $45 \%$ \\
\hline Journal article & 8 & $7 \%$ & 6 & $11 \%$ & 8 & $24 \%$ & 22 & $16 \%$ & 1 & $2 \%$ & 13 & $12 \%$ \\
\hline Document & 8 & $7 \%$ & 16 & $30 \%$ & 11 & $32 \%$ & 9 & $7 \%$ & 2 & $4 \%$ & 18 & $17 \%$ \\
\hline Thesis & 9 & $8 \%$ & 1 & $2 \%$ & - & - & 10 & $8 \%$ & - & - & 7 & $7 \%$ \\
\hline Web page & 11 & $10 \%$ & 24 & $44 \%$ & 7 & $21 \%$ & 28 & $21 \%$ & 2 & $4 \%$ & 18 & $17 \%$ \\
\hline Interview & - & - & - & - & - & - & 1 & $1 \%$ & - & - & - & - \\
\hline Encyclopedia article & - & - & - & - & - & - & 1 & $1 \%$ & - & - & - & - \\
\hline Conference paper & - & - & - & - & 1 & $3 \%$ & 3 & $2 \%$ & - & - & 1 & $1 \%$ \\
\hline Newspaper article & - & - & 1 & $2 \%$ & 2 & $6 \%$ & 1 & $1 \%$ & - & - & - & - \\
\hline Blog post & - & - & - & - & - & - & - & - & 1 & $2 \%$ & 1 & $1 \%$ \\
\hline Total & 112 & $100 \%$ & 54 & $100 \%$ & 34 & $100 \%$ & 134 & $100 \%$ & 46 & $100 \%$ & 105 & $100 \%$ \\
\hline
\end{tabular}

\subsection{Quantitative Analysis of the Given Research}

The data the quantitive analysis of the proposal model in each function are shown in Table 6.

According to the process meta-analytic carried out to classify the 485 sources according to the type of the resource, (a) administrative management was obtained $67.9 \%$ for books; (b) teaching, $44.4 \%$ of the resources used as institutional websites public or private; (c) student progress, $32.4 \%$ for documents; (d) support services, $44 \%$ on books in the same way for (e) research, $87 \%$ in books and to (f) university social importance a $44.8 \%$ in books. 


\subsection{Strategic Model of University Management.}

Eight models of evaluation and institutional self-evaluation for accreditation applied by several entities in America and Europe took as the basis for the creation of the strategic model of University management. The proposed model contains six functions, 12 areas, 28 features, 111 quality standards, indicators 188 and 937 evidence. To collect the information is proposed to the designed a virtual, dynamic and interactive platform called system of accreditation and strategic assessment for higher education (SAEES), which creates an experience for the 28 units of analysis of information, known as informants: Dean, Sub Dean, Coordinator of career, General Secretariat, Secretariat of the career, teachers, students, administrative staff, workers, Committee on bonding, Academic research, human resources, planning unit, titration unit, Commission of intern, qualified informants, documentation centre and library, Department of physical development, computer unit, financial management, University welfare, monitoring unit to Alumni/graduates, physical culture, student representative, graduates, graduates and staff support to teaching, who have the responsibility of delivering evidence for the appropriateness of activities within its competence fulfillment.

The model it's valid by 514 customer opinions (which let the opinions to be evaluated) and 423 interviews (that allow analyzing documentary information), to evaluate the evidence is considered a four-level scale. The indicators are presented in four dimensions and 12 basic variables of excellence, which assesses the subject of quality and relevance that should be considered in the development of the activities to be pursued to reach for the fulfillment of the indicator. The coding of the indicators consists of two parts: an alphabetical and other numerical starting from left to right. In the alphabetical part two first letters we directed to the dimension, the following letters characterise the variable, the first numerical digit shows the function, the second level and the third is the logical sequence of the dimension and a variable within the scope. As shown in Figure 3.

Figure 3 proposes a model with six functions, which includes processes and modular activities of the primordial elements that intervene in university work, referred to as functions: administration, teaching, student progress, support services, research and university social transcendence [18] [19] [20] [21].

\subsubsection{Administrative Management Function}

Administrative Management in Higher Education allows to analyze two areas: (a) internal, is responsible for implementing improvements to satisfy students in the use of libraries, recreational areas, simulators, medical and psychological dispensaries; (b) external, national and international agreements are held to participate in forums, student scholarships, study programs and all activities that allow the well-being of the applicant [22].

Accordingly, by their level of academic importance was weighted to the field (a) one mission and institutional plan with a value of 5\%; (b) two administration 


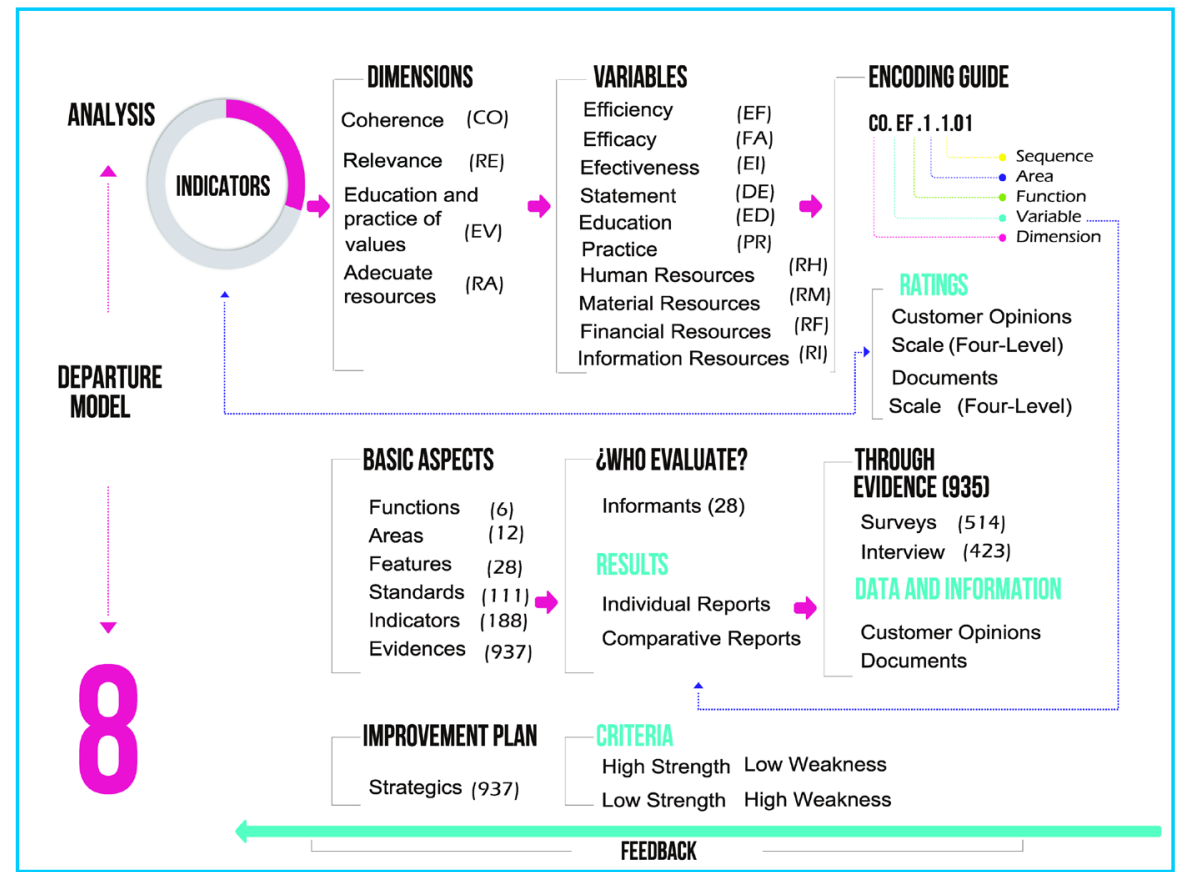

Figure 3. Strategic model for the management (university use).

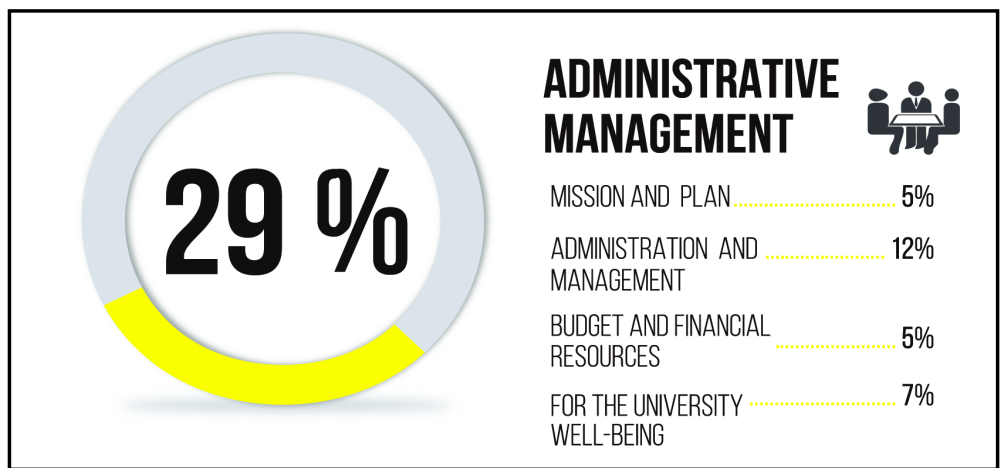

Figure 4. Weighting of the administrative management function.

and management, 12\%; (c) three budget and financial resources, 5\%; and (d) four university welfare, $7 \%$. Values that they generate $29 \%$ for administrative management, about $100 \%$ of the strategic model of University Management raised, are as shown in Figure 4.

\subsubsection{Teaching Function}

This function comprises indicators that refer to activities that develop one of the main elements of the educational process as it is teaching. A teacher is a suitable person to develop human progress, the Enhancer of knowledge of students. The importance of not only teaching focuses on issue hours of classes, but rather focuses on entering the mind of the students so they can acquire a favorable society intellectual thought, exploiting way consent the knowledge [23] [24]. However the importance of a faculty is not fundamental in its entirety because despite being the main actor for the teaching of a new knowledge, it is the student who must acquire and apply the taught, establishing him as the indispensable element 
within University Learning [25].

By their level of importance and value to the University community is weighted to the field five, academic staff with a value of $12 \%$, generating $12 \%$ for teaching, as shown in Figure 5.

\subsubsection{Student Progress Function}

The students deserve a quality education with worthy knowledge in its academic and pedagogical training through an effective methodology that allows you to face a world with several problems. The students are in need of receiving different psycho-pedagogical theories that reinforce learning and motivation for the student progress, guaranteeing education first for the advancement of society. Similarly, article 5 of the organic law of higher education says that the quality and relevance of education is a right which guarantees equal opportunities in the process of training [26].

Thus was weighted to the field number six, curriculum and training process with a value of $15 \%$ and to the field seven, pedagogy with a value of $3 \%$, weighting that generates $18 \%$ for student progress function, as shown in Figure 6.

\subsubsection{Support Services Function}

When the quality of the different services on the institutions: library, computer laboratories, maintenance cleaning [27]. Algunas instituciones de educación superior manifiestan, que la calidad de la enseñanza se ve reflejada Some higher education institutions express, that the quality of education is reflected in the particularity of the services that provide daily institutions, since they influence

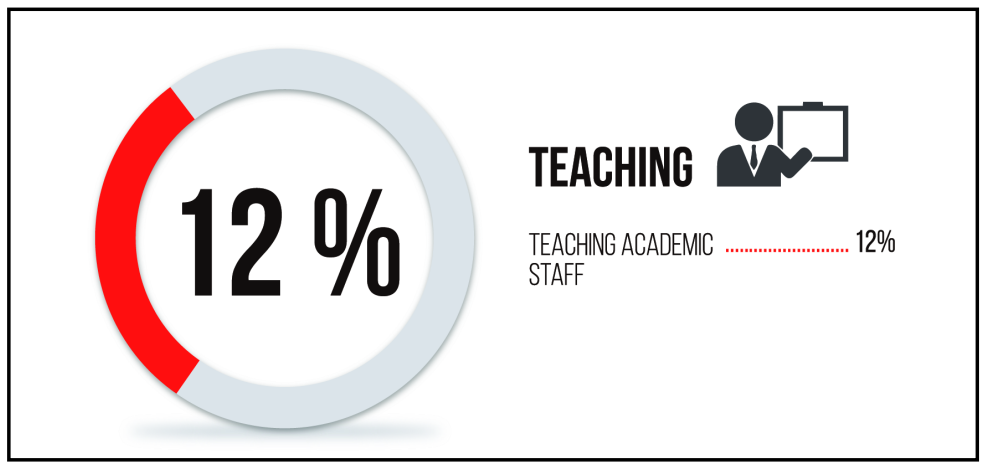

Figure 5. Weighting of the teaching function.

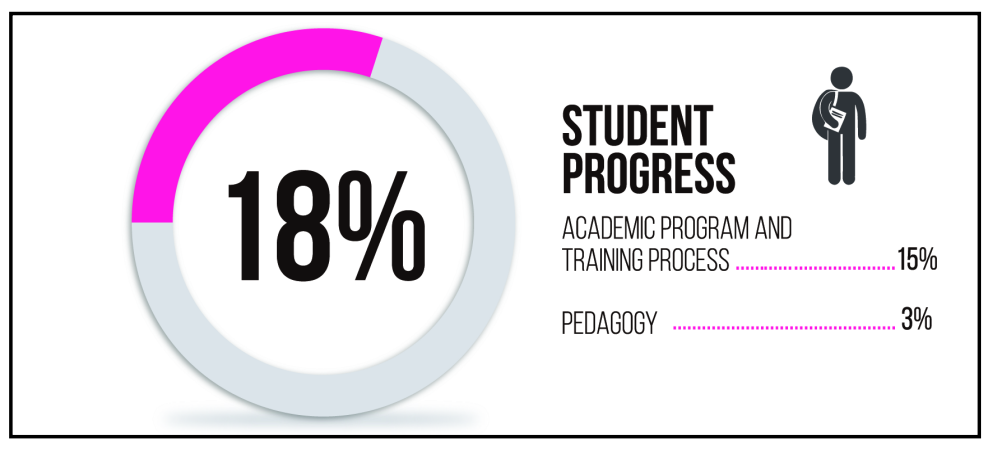

Figure 6. Weighting of the student progress function. 
the motivation of the entire University community, as well as aspects academic support to cultural, sports themes and services coexistence [28]. Therefore, by their level of importance and rating for the institution, is weighted to the field eight, documentation centre with a value of $7 \%$ and for the so-called nine, institutional infrastructure, $6 \%$ generating $13 \%$ for the support services feature, as shown in Figure 7.

\subsubsection{Research Function}

The University was currently not should focus only on the transmission of information, because its management engine is the generation of new knowledge that contributes to improve the quality of life of current and future of the whole society, therefore to develop the art experts think, analyze, investigate and fully exploit scarce and available resources is essential to promote a research culture in the training of new professionals [29] [30].

If the universities promote autonomous learners they deliver to the society beings capable of changing humanity, a world and a universe increasingly interactive and demanding, so the Ecuadorian Government tries to strengthen the investigative field through scholarships and national and international exchanges for teachers and researchers in order to acquire new knowledge, enabling you to develop your own judgment and creativity [31]. In this sense, is weighted to the field 10 so-called scientific and technological research with $14 \%$, value that generates $14 \%$ for the research function, as shown in Figure 8.

\subsubsection{University Social Importance Function}

Factors to evaluate to determine the relevance and quality of higher education

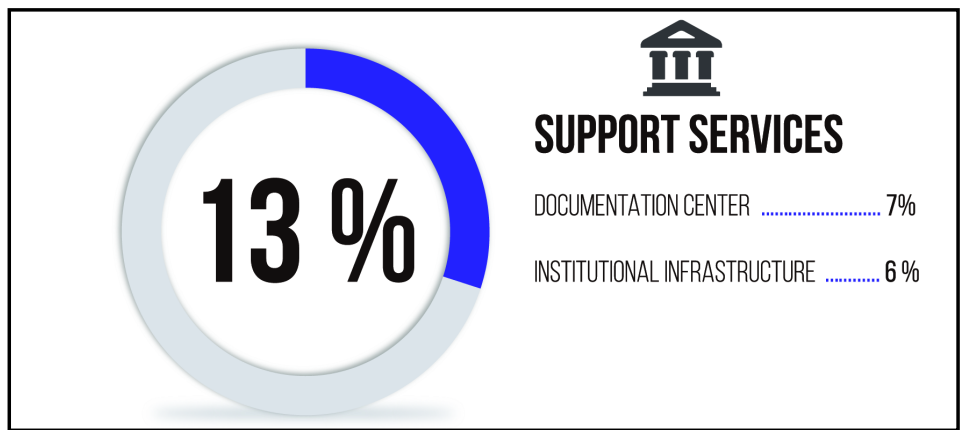

Figure 7. Weighting of the support services function.

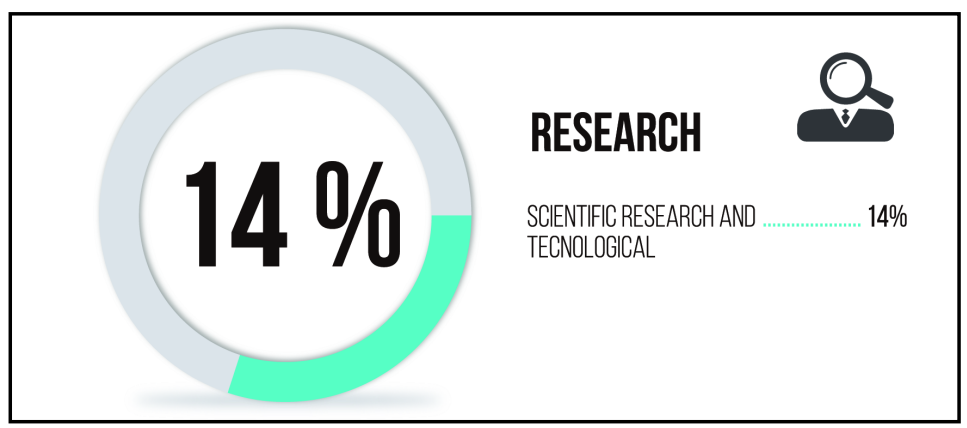

Figure 8. Weighting of the research function. 
vary depending on the perspective analyzed in each country, in the case of Spain the bodies responsible for custom learning in higher education are grouped in the following areas: organization and management, curriculum design, educational environment, skills of teachers, pedagogical processes and social significance, the latter include activities related to those that are grouped in connection with the community [32], for this reason changing the function called bonding with the community to university Social transcendence. In Ecuador the system of higher education in chapter I, article 17 expressed that institutions will maintain a relationship of protection and cooperation among them and with the society, based on the principles of Justice and equity that authorizes law [26].

I.e., actions developed according to the needs of the local and national region (bonding with the community) enable the University community to be an entity with autonomy socially responsible, in this sense we have inclusion of university social responsibility, in order to create professional integrals with multivariate thinking not only as an expert, but as a citizen in search of the good life of a developing State generates a university social importance as says it the National Ministry of planning and development [33] [34].

Therefore, with the information provided above is it weighted the field 11 and 12 link with the community and institutional impact with a value of 7\% for each; this form generates $14 \%$ for university social transcendence function, as shown in Figure 9.

\section{Conclusions}

1) Was considered the accreditation as the value judgment that examines the suitability and relevance of institutional programs, process that is performed by the fulfilment of quality standards that establish the organizations in charge of regulating the excellence in higher education For the study eight models prevailed that contributed significantly to the design of the proposal, therefore this management tool will allow the IES to raise its level of academic excellence according to national and international scenarios.

2) To substantiate the construct of study criteria for strategic model of University management, using a systematic methodology of management of information called meta-analysis, we evaluated strategies the literature search, the

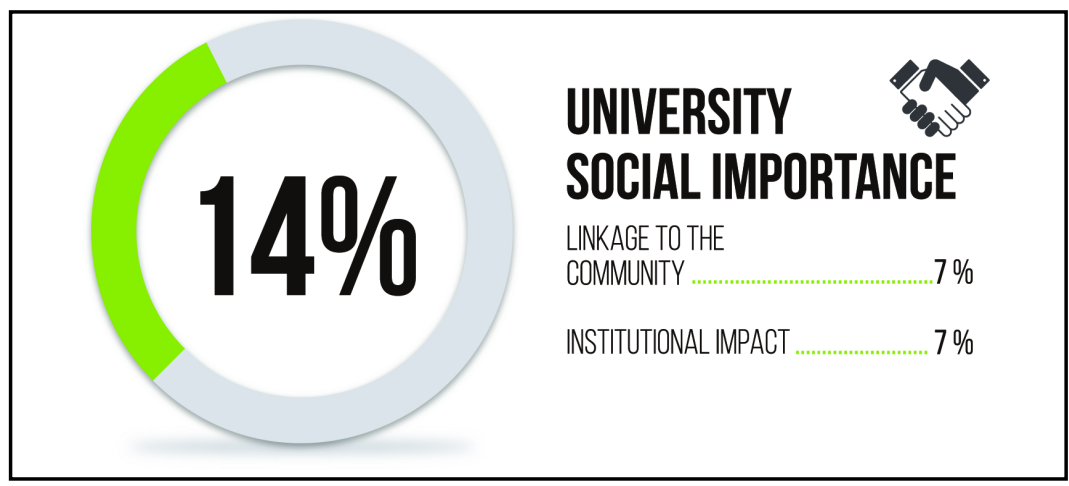

Figure 9. Weighting of the university social importance function. 
criteria for inclusion and exclusion of the articles, the quality and quantitative analysis of the studies reviewed, the research was used in mostly books from the Google Books database, sources with no more than five years, Spanish-language old and established a homogeneity with an average of 0.54 based on the criteria of the authors outperformed the heterogeneity.

3) Identified six elements guidelines or strategic functions of the University management that contribute to the development of institutional quality, administrative management is evaluated on $29 \%$, he is responsible for the planning, organization, direction, and control of compliance and achievement of institutional objectives, is composed of four areas, (a) mission and plan has a weighting of $5 \%$, contains two properties, four banners, 11 quality indicators, 47 evidence and two evaluation tools; (b) administration and management has a value of $12 \%$, consists of four features, 16 standards, 28 indicators of quality, 88 evidence and two evaluation tools; (c) budget and financial resources has a value of $5 \%$ and is composed of a characteristic, nine standards, 13 indicators of quality, 21 evidence and two evaluation tools; and (d) University welfare with a value of $7 \%$ that contains a feature, six standards, 16 indicators of quality, 47 evidence and two evaluation tools.

- Teaching considers $12 \%$, its purpose is to organize those activities developed by one of the major players in the University level as it is the teacher, this function contains a single field named academic staff, therefore assessed above $12 \%$, contains three features, 11 banners, 18 quality indicators, 83 evidence and two evaluation tools.

- Student progress is evaluated on $18 \%$, it is the axis facing the psycho-pedagogic pressures to improve the quality of education, thus becoming a priority strategy for IES, is composed of two fields: (a) academic program and learning process has a weighting of $15 \%$, contains six features, 20 standards, 25 quality indicators, 87 evidence and two instruments of assessment; and (b) pedagogy is evaluated about $3 \%$, it contains two features, four standards, five indicators of quality, 13 evidence and two evaluation tools.

- Support services are evaluated on $13 \%$, it is considered that education is conditioned by the services which daily provide the IES and influence the motivation of the entire University community. This function is composed of two fields, (a) documentation centre has a weighting of $7 \%$, contains a feature, five standards, 12 indicators of quality, 36 evidence and two evaluation tools; and (b) institutional infrastructure is evaluated about $6 \%$, consists of two features, four standards, nine quality indicators, 30 evidence and two evaluation tools.

- Research is evaluated on a total of $14 \%$, is the management engine for the generation of professionals who contribute to the creation of new knowledge and improve the quality of life of current and future of society It is comprised of a field named scientific and technological research with a $14 \%$ weighting, contains two properties, 15 standards, 24 indicators of quality, 65 evidence and two evaluation tools.

- University Social importance is evaluated on a total of $14 \%$, is the shaft that 
works according to the needs of the region locally and nationally to enabling the University to be an entity with socially responsible autonomy, is composed of two fields, (a) link with the community has a weighting of 7\%, contains a feature, five standards, 10 quality indicators, 27 evidence contains and two instruments of evaluation; and (b) institutional impact with a weight of 7\%, three features, 13 standards, 17 indicators of quality, 30 evidence and two evaluation tools.

Higher education institutions have a responsibility to train professionals with procedural, cognitive ability and attitude of quality in order to face the new challenges of the globalized society, is indispensable to use tools of management and organizational growth, one of the tools most used by the directors of the institutions and all the agencies that govern the educational system the University evaluation, is the study model evaluates six strategic axes: administrative management, teaching, student progress, support services, research and University Social importance.

\section{References}

[1] Ramírez, M. (2013) La planificación estratégica en las instituciones de educación superior mexicanas: De la retórica a la práctica. CPU-e, Revista de Investigación Educativa, 4, 119-129.

[2] Garg, A., Hackam, D. and Tonelli, M. (2008) Systematic Review and Meta-analysis: When One Study Is Just Not Enough. Clinical Journal of the American Society of Nephrology, 3, 253-260. https://doi.org/10.2215/CJN.01430307

[3] Haidich, A. (2010) Meta-Analysis in Medical Research. Hippokratia, 14, 29-37.

[4] Hattie, J., Rogers, J. and Swaminathan, H. (2014) The Role of Meta-Analysis in Educational Research. In: Reid, A., Hart, P. and Peters, M., Eds., A Companion to Research in Education, Springer Netherlands, New York City, 197-207.

http://link.springer.com https://doi.org/10.1007/978-94-007-6809-3_26

[5] Marín, F., Sanchez, J. and López, J. (2009) El metaanálisis en el ámbito de las ciencias de la salud: Una metodología imprescindible para la eficiente acumulación del conocimiento. Elsevier Doyma, 3, 8. https://doi.org/10.1016/j.ft.2009.02.002

[6] Fuensanta, M. (2015) Lectura crítica de un metaanálisis de una revisión sistemática. Murciasalud. Recuperado a partir de https://www.murciasalud.es

[7] León, S. (2001) Metodología de los estudios de meta-análisis en la investigación clínica. Revista Mexicana de Ortopedia y Traumatología, 15, 7.

[8] INSHT. (2015) Revisión sistemática y meta-análisis en seguridad y salud laboral (II): etapas. Instituto Nacional de Seguridad e Higiene en el Trabajo, 4.

[9] Sandoya, E. (2008) Metaanálisis: Fortalezas y debilidades, 23, 13.

[10] CINDA. (1994) Modelo de autoevaluación para instituciones de Educación Superior. Santiago de Chile: CINDA. Recuperado a partir de http://www.cinda.cl

[11] Casal, G., Vadillo, Ó., Pagani, R., Sierra, J.C., Zych, I. and Castro, Á. (2009) Comparación de los indicadores de la calidad de las universidades. Revista de Universidades y Sociedad del Conocimiento, 6, 9-21.

[12] Carot, J., Henrique, P., Haug, G., Mora, J., Ristoff, D., Vidal, J., González, E., et al. (2012) Sistema básico de indicadores para la educación superior de América Latina. Editorial Universitat Politècnica de València, Valencia. http://www.infoaces.org

[13] ENQA, ESU, EUA, EURASHE, EI, BUSINESSEUROPE and EQAR (2015) Criterios 
y directrices para la garantía de calidad en el espacio europeo de educación superior. EURASHE, Belgium. http://www.eua.be

[14] UNESCO (2000) Desarrollo de indicadores en Educación en América Latina y el Caribe. UNESCO-OREALC. http://www.cepal.org

[15] ALAFEC (2014) Modelo de indicadores de gestión académica. ALAFEC. http://www.alafec.unam.mx

[16] CONEA (2010) Modelo de autoevaluación institucional para la acreditación. Estatal presentado en PEAE, Ecuador.

[17] CEAACES (2012) Modelo genérico de evaluación del entorno de aprendizaje de las carreras presenciales y semi presenciales de las universidades y escuelas politécnicas del Ecuador. CEAACES. http://www.ceaaces.gob.ec

[18] Campos, J. and Chinchilla, A. (2009) Reflexiones acerca de los desafíos en la formación de competencias para la investigación en Educación Superior. Revista Electrónica Actualidades Investigativas en Educación, 9, 20.

[19] Solís, A. (2010) Hacia el desarrollo de la educación superior virtual. Revista mexicana de investigación educativa, 15, 185-189.

[20] Ministerio de Educación de Ecuador (2012) Indicadores Educativos 2011-2012. Ministerio de Educación de Ecuador.

http://educacion.gob.ec

[21] Navarrete, F. (2015) La Educación Superior Como Dinamizadora De La Responsabilidad Social Empresarial: Un Estudio Comparado Entre Los Futuros Dirigentes Empresariales En América Latina. Liber Factory, Madrid-España. https://books.google.com.ec

[22] Díaz, M.R.O. and Rangel, P.E.S. (2010) Un enfoque de mercadeo de servicios educativos para la gestión de las organizaciones de educación superior en colombia: El modelo migme. http://www.scielo.org.co/pdf/rfce/v18n2/v18n2a07

[23] Beraza, M.Á.Z. and Cerdeiriña, M.A.Z. (2011) Profesores y profesión docente: Entre el "ser" y el "estar". Narcea Ediciones. https://books.google.com.ec

[24] El-Sahili, L.F. (2010) Psicologia para el docente: Consideraciones sobre los riesgos y desafíos de la profesión magisterial. Vol. 1, Universidad de Guanajuato, Mexico. https://books.google.com.ec

[25] Zabalza, M.Á. and Beraza, M.Á.Z. (2013) Competencias docentes del profesorado universitario: Calidad y desarrollo profesional. Narcea Ediciones. https://books.google.com.ec

[26] Pozo, H. (2010) Ley Orgánica de Educación Superior. Suplemento. http://www.ceaaces.gob.ec

[27] Carreño de Celis, R., Salgado González, L., Fernández Oliva, B., Pardo, A. and Elina, M. (2010) Factores que intervienen en el proceso de formación de los profesionales universitarios de la salud. Educación Médica Superior, 23.

[28] Duque, E.J. and Gómez, Y.D. (2014) Evolución conceptual de los modelos de medición de la percepción de calidad del servicio: Una mirada desde la educación superior. Suma de Negocios, 5, 180-191.

[29] Guzmán, J.C. (2011) La calidad de la enseñanza en educación superior Qué es una buena enseñanza en este nivel educativo? Perfiles Educativos, 33, 129-141.

[30] Vargas, D. (2011) Seminario "La Investigación en la Educación Superior: Presente y Futuro"-Centro Virtual de Noticias de Educación. Presentado en Centro Virtual de Noticias de la Educación, ACAC-Asociación Colombiana para el Avance de la Ciencia, Colombia, 5. http://www.mineducacion.gov.co

[31] Prometeo (2016) José Luis Paz, la importancia de saber hacer investigación 
científica. http://prometeo.educacionsuperior.gob.ec

[32] Velásquez, C. (2010) Criterios e indicadores para evaluar la calidad de la educación en instituciones de educación superior. http://www.ucv.ve

[33] Ministerio de Educación (2015) Educación para la Democracia y el Buen Vivir Ministerio de Educación. http://educacion.gob.ec

[34] Secretaria Nacional de Planificación y Desarrollo (2013, 2017) Presentación-Plan Nacional 2013-2017. Recuperado 15 de junio de 2016. http://www.buenvivir.gob.ec

Submit or recommend next manuscript to SCIRP and we will provide best service for you:

Accepting pre-submission inquiries through Email, Facebook, LinkedIn, Twitter, etc. A wide selection of journals (inclusive of 9 subjects, more than 200 journals)

Providing 24-hour high-quality service

User-friendly online submission system

Fair and swift peer-review system

Efficient typesetting and proofreading procedure

Display of the result of downloads and visits, as well as the number of cited articles Maximum dissemination of your research work

Submit your manuscript at: http://papersubmission.scirp.org/

Or contact jssm@scirp.org 